\title{
The Influence of Sulphate Deposition on the Seasonal Variation of Peat Pore Water Methyl Hg in a Boreal Mire
}

\author{
Inger Bergman ${ }^{1}$, Kevin Bishop ${ }^{2,3}$, Qiang Tu ${ }^{4}$, Wolfgang Frech ${ }^{4}$, Staffan Åkerblom², Mats Nilsson ${ }^{1 *}$
}

1 Department of Forest Ecology and Management, Swedish University of Agricultural Sciences, Umeå, Sweden, 2 Department of Aquatic Sciences and Assessment, Swedish University of Agricultural Sciences, Uppsala, Sweden, 3 Department of Earth Sciences, Uppsala University, Uppsala, Sweden, 4 Department of Analytical Chemistry, University of Umeå, Umeå, Sweden

\begin{abstract}
In this paper we investigate the hypothesis that long-term sulphate $\left(\mathrm{SO}_{4}{ }^{2-}\right)$ deposition has made peatlands a larger source of methyl mercury $(\mathrm{MeHg})$ to remote boreal lakes. This was done on experimental plots at a boreal, low sedge mire where the effect of long-term addition of $\mathrm{SO}_{4}{ }^{2-}$ on peat pore water $\mathrm{MeHg}$ concentrations was observed weekly throughout the snow-free portion of 1999 . The additions of $\mathrm{SO}_{4}{ }^{2-}$ started in 1995 . The seasonal mean of the pore water $\mathrm{MeHg}$ concentrations on the plots with $17 \mathrm{~kg} \mathrm{ha}^{-1} \mathrm{yr}^{-1}$ of sulphur (S) addition $\left(1.3 \pm 0.08 \mathrm{ng} \mathrm{L}{ }^{-1}, \mathrm{SE} ; \mathrm{n}=44\right)$ was significantly $(\mathrm{p}<0.0001)$ higher than the mean MeHg concentration on the plots with $3 \mathrm{~kg} \mathrm{ha}^{-1} \mathrm{yr}^{-1}$ of ambient $\mathrm{S}$ deposition $\left(0.6 \pm 0.02 \mathrm{ng} \mathrm{L}^{-1}, \mathrm{SE} ; \mathrm{n}=44\right)$. The temporal variation in pore water $\mathrm{MeHg}$ concentrations during the snow free season was larger in the S-addition plots, with an amplitude of $>2 \mathrm{ng} \mathrm{L}^{-1}$ compared to $+/-0.5 \mathrm{ng} \mathrm{L^{-1 }}$ in the ambient $S$ deposition plots. The concentrations of pore water $\mathrm{MeHg}$ in the S-addition plots were positively correlated $\left(r^{2}=0.21 ; p=0.001\right)$ to the groundwater level, with the lowest concentrations of $\mathrm{MeHg}$ during the period with the lowest groundwater levels. The pore water $\mathrm{MeHg}$ concentrations were not correlated to total $\mathrm{Hg}$, DOC concentration or $\mathrm{pH}$. The results from this study indicate that the persistently higher pore water concentrations of $\mathrm{MeHg}$ in the S-addition plots are caused by the long-term additions of $\mathrm{SO}_{4}{ }^{2-}$ to the mire surface. Since these waters are an important source of runoff, the results support the hypothesis that $\mathrm{SO}_{4}{ }^{2-}$ deposition has increased the contribution of peatlands to $\mathrm{MeHg}$ in downstream aquatic systems. This would mean that the increased deposition of $\mathrm{SO}_{4}{ }^{2-}$ in acid rain has contributed to the modern increase in the MeHg burdens of remote lakes hydrologically connected to peatlands.
\end{abstract}

Citation: Bergman I, Bishop K, Tu Q, Frech W, Åkerblom S, et al. (2012) The Influence of Sulphate Deposition on the Seasonal Variation of Peat Pore Water Methyl $\mathrm{Hg}$ in a Boreal Mire. PLoS ONE 7(9): e45547. doi:10.1371/journal.pone.0045547

Editor: Sandra Maria Feliciano de Oliveira Azevedo, Federal University of Rio de Janeiro, Brazil

Received June 26, 2012; Accepted August 23, 2012; Published September 21, 2012

Copyright: (c) 2012 Bergman et al. This is an open-access article distributed under the terms of the Creative Commons Attribution License, which permits unrestricted use, distribution, and reproduction in any medium, provided the original author and source are credited.

Funding: Funding for this research was provided by the Swedish Foundation for Strategic Environmental Research and the Department of Environmental Assessment at the Swedish University of Agricultural Sciences. The funders had no role in study design, data collection and analysis, decision to publish, or preparation of the manuscript.

Competing Interests: The authors have declared that no competing interests exist.

*E-mail: Mats.B.Nilsson@slu.se

\section{Introduction}

Historically, human activities have caused large emissions of mercury $(\mathrm{Hg})$ to the atmosphere. This has contributed to widespread $\mathrm{Hg}$ pollution and increased concentrations in the biota e.g. fish. Deposition of $\mathrm{Hg}$ in the boreal region modelled by EMEP [1] show relatively low rates in the Nordic countries, deposition rates that also are verified by moss monitoring [2]. The concentrations of $\mathrm{Hg}$ in fish are higher, though, than in other regions with similar or even higher deposition rates [3]. One key to the difference between $\mathrm{Hg}$ deposition and the high degree of bioaccumulation is one particular species of $\mathrm{Hg}$, methyl mercury $(\mathrm{MeHg})$ that is most prone to bioaccumulation [4-6]. The cycling of $\mathrm{MeHg}$ in boreal catchments is complex and involves numerous biogeochemical and physical controls. Therefore, it is important to elucidate the impact of these factors on $\mathrm{MeHg}$ production.

Important sources of $\mathrm{MeHg}$ loadings to lakes are direct precipitation [7,8], run-off from wetlands [9-11], and in-lake methylation [12-14]. Mass-balance calculations, however have revealed that often neither precipitation, nor in-lake methylation can account for the total amount of $\mathrm{MeHg}$ in the catchment runoff [15] or in lakes [16-18]. The runoff of $\mathrm{MeHg}$ from catchments and the levels found in fish can vary considerably between different catchments with similar levels of atmospheric deposition $[5,19]$. This suggests that the $\mathrm{MeHg}$ species is produced within the catchments.

Boreal wetlands have been identified as an important source of $\mathrm{MeHg}$ to lakes [16,20-23] though there is considerable variability in the strength of these hotspots across the landscape [24-26]. One factor affecting the significance of wetland sources can be the proportion of mires [27] or riparian zones [28,29] in the catchment. While wetlands generally are considered sources of $\mathrm{MeHg}$ one alder swamp have actually been found to be a sink of $\mathrm{MeHg}$ [25]. Another possible factor in the catchment production of $\mathrm{MeHg}$ is sulphate $\left(\mathrm{SO}_{4}{ }^{2-}\right)$ deposition which stimulates the production of $\mathrm{MeHg}[9,12,30]$.

The importance of sulphate-reducing bacteria (SRB) for methylation of $\mathrm{Hg}$ is well-documented [12,31,32]. The possibility that $\mathrm{SO}_{4}{ }^{2-}$ in "acid-rain" has enhanced in-lake methylation was suggested by Gilmour and colleagues [12,33]. A number of studies now suggest that the availability of $\mathrm{SO}_{4}{ }^{2-}$ for $\mathrm{SRB}$ is a major factor regulating the concentration of $\mathrm{MeHg}$ in mire pore water. Branfireun et al. [30] suggested $\mathrm{SO}_{4}{ }^{2-}$ reduction in the anoxic zone of mires and riparian wetlands as the functional explanation 
for the increased concentrations of $\mathrm{MeHg}$ in runoff from boreal wetlands. In that study addition of $\mathrm{SO}_{4}{ }^{2-}$, corresponding to $28 \mathrm{~kg}$ $\mathrm{SO}_{4}{ }^{2-} \mathrm{ha}^{-1}$, to a boreal peatland increased the pore-water concentrations of $\mathrm{MeHg}$ from 2 to $4 \mathrm{ng} \mathrm{L}{ }^{-1}$ within 24 hours. The $\mathrm{MeHg}$ concentrations, however, returned to ambient levels after 5 days. In constructed wetlands, Harmon et al. [34] found that $\mathrm{SO}_{4}{ }^{2-}$ amendments gave significantly higher $\mathrm{MeHg}$ pore water concentrations over the course of one year. In a mescosm experiment, Mitchell et al. [35] found that $\mathrm{SO}_{4}{ }^{2-}$ additions significantly increased $\mathrm{MeHg}$ pore water concentrations, while additions of different carbon substrates alone did not have an effect. Combined $\mathrm{SO}_{4}{ }^{2-}$ and carbon $(\mathrm{C})$ additions, however, gave the largest increases, providing an explanation of why hotspots of $\mathrm{MeHg}$ appear in mires where there are inputs of both $\mathrm{C}$ and $\mathrm{SO}_{4}{ }^{2-}$ [23].

An experiment to simulate the effect of atmospheric $\mathrm{SO}_{4}{ }^{2-}$ at the ecosystem scale by sprinkling $\mathrm{SO}_{4}{ }^{2-}$ solutions systematically across a mire for one snow-free season also found a significant influence on $\mathrm{MeHg}$, both in pore water and in the runoff from the mire [9]. $\mathrm{SO}_{4}{ }^{2-}$ additions in that experiment were made on five occasions, and the effects on pore water concentrations varied considerably. This may have to do with the relatively short term additions of $\mathrm{SO}_{4}{ }^{2-}$ to the system, a feature common to most other studies on how $\mathrm{SO}_{4}{ }^{2-}$ influences $\mathrm{MeHg}$ in mires.

Pore [36] and run off [9] water from wetlands responded to experimentally elevated sulphur (S) deposition with an increased potential to produce $\mathrm{MeHg}$. Branfireun et al. [36] found a tripling of peat pore water $\mathrm{MeHg}$ in plots exposed to two years of elevated $\mathrm{S}$ deposition $\left(20 \mathrm{~kg} \mathrm{~S} \mathrm{ha} \mathrm{yr}^{-1}\right.$ ) compared to plots with the ambient deposition in N. Sweden $\left(3 \mathrm{~kg} \mathrm{~S} \mathrm{ha}^{-1} \mathrm{yr}^{-1}\right)$, five weeks after the most recent experimental $\mathrm{SO}_{4}{ }^{2-}$ amendment had been made. An almost equally large increase (2.4 times) in stream water $\mathrm{MeHg}$ concentrations were also found after experimental additions of $\mathrm{SO}_{4}{ }^{2-}$ of an experimental wetland in northeastern Minnesota [9]. Such long-term effects would greatly increase the potential significance of $\mathrm{S}$ deposition for $\mathrm{MeHg}$-loading to the aquatic ecosystem.

Observation of elevated $\mathrm{MeHg}$ at a single point in time is not, however, sufficient to prove a persistent effect since other factors are also important for the regulation of $\mathrm{SO}_{4}{ }^{2-}$ reduction (and hence any sustained effect of $\mathrm{SO}_{4}{ }^{2-}$ ). These factors include the occurrence of competing e acceptors e.g. oxygen which is mainly determined by the prevalence of saturated conditions [37,38], availability of easily degradable $\mathrm{G}$ for the SRB $[35,39,40]$ and temperature [41]. To investigate the importance of these factors for the persistence and magnitude of the "acid-rain" effect, we studied the differences in temporal variation of peat pore-water $\mathrm{MeHg}$ between plots exposed to ambient (ca $3 \mathrm{~kg} \mathrm{~S} \mathrm{ha}^{-1} \mathrm{yr}^{-1}$ ) and five years of enhanced $\mathrm{SO}_{4}{ }^{2-}$ deposition $\left(20 \mathrm{~kg} \mathrm{~S} \mathrm{ha}^{-1} \mathrm{yr}^{-1}\right)$ in a low sedge mire in northern Sweden during one snow-free period of five months duration. On three occasions we sampled these plots at four depths to get a deeper profile of pore water $\mathrm{MeHg}$. Our main hypothesis is that elevated pore-water $\mathrm{MeHg}$ concentrations are maintained by an increased pool of $\mathrm{S}$ (due to enhanced deposition) which can be recycled at the mire surface through reduction of $\mathrm{SO}_{4}{ }^{2-}$ (to e.g. $\mathrm{HS}^{-}$) and subsequent reoxidation of reduced $\mathrm{S}$ species to $\mathrm{SO}_{4}{ }^{2-}$. Since we are interested in ascertaining the effect of this process on $\mathrm{MeHg}$ loading to lakes and their biota, we have sampled the uppermost ten centimetres below the water table every week during the study period, regardless of the water table depth relative to the mire surface. This is the water most likely to compose the runoff from wetlands to downstream lakes [42].

\section{Materials and Methods}

\section{Field Experimental Setup and Sampling}

The pore water samples were collected from a low sedge mire, Degerö Stormyr (Lat. $64^{\circ} 11^{\prime} \mathrm{N}$, Long. $19^{\circ} 33^{\prime} \mathrm{E}$, altitude $270 \mathrm{~m}$ a s l) situated $70 \mathrm{~km}$ from the coast of the Gulf of Bothnia, Sweden. The experimental site is part of the Vindeln Research Forests, Swedish University of Agricultural Sciences. The experimental setup was established in 1995 and is based on the manipulation of 20, $4 \mathrm{~m}^{2}$ plots, each of which are isolated from the surroundings by a $0.5 \mathrm{~m}$ deep plastic frame inserted to a depth of $0.4 \mathrm{~m}$ in the peat. Together with one extra control plot without plastic frames, there were a total of 21 experimental plots. In this study we utilised four of these plots, two receiving ambient levels of $\mathrm{S}\left(3 \mathrm{~kg} \mathrm{~S} \mathrm{ha}^{-1} \mathrm{yr}^{-1}\right)$ from the precipitation, and two plots receiving experimental additions, applied at five occasions during the snow free period, which together with the ambient input equals $20 \mathrm{~kg} \mathrm{~S}^{-1} \mathrm{yr}^{-1}$. A thorough description of the experiment is given in Granberg et al. [43] and Wiedermann et al. [44].

Pore water from these plots was sampled every week between May $26^{\text {th }}$ and October $20^{\text {th }}$ in $1999,0-10 \mathrm{~cm}$ beneath the groundwater level (GWL) at the time of sampling. In addition, pore water was sampled from $10-20 \mathrm{~cm}, 20-30 \mathrm{~cm}$, and $30-$ $40 \mathrm{~cm}$ beneath the GWL on June $23^{\text {rd }}$, July $28^{\text {th }}$, and August $25^{\text {th }}$ 1999. The actual GWL was measured at 5 evenly distributed points within each plot. Runoff water in the stream draining the mire was also sampled each week, starting June $23^{\text {rd }}$.

Subsamples for dissolved organic carbon (DOC) were kept cool and in the dark before analysis within one month after sampling. The subsamples for anions were preserved by freezing, and the subsamples for cation analysis were preserved with suprapur sulphuric acid. The anions and cations were all analyzed within six months of sampling.

The DOG was determined by analytical combustion (Shimadzu, DOC-500). Pore water concentration of $\mathrm{SO}_{4}{ }^{2-}$ was determined by suppressed ion chromatography (Shimadzu, UV detector SPD-6A) using $0.5 \mathrm{mM}$ sulfosalicyl acid as the mobile phase. After filtration, $\mathrm{pH}$ was determined in all pore water samples. Total $\mathrm{S}, \mathrm{Hg}_{\text {tot }}$ and $\mathrm{MeHg}$ in the solid peat were determined on freeze-dried and ground peat samples taken at 0 $5 \mathrm{~cm}, 5-10 \mathrm{~cm}, 10-20 \mathrm{~cm}$, and $20-40 \mathrm{~cm}$ beneath the surface of the sphagnum moss. The solid samples were collected on June $24^{\text {th }}$ 1999. For total S, the samples were digested with $\mathrm{HNO}_{3}+\mathrm{HClO}_{4}$ and thereafter analysed using Inductive Coupled Plasma - Atomic Emission Spectrometer (ICP - AES, Perkin Elmer).

Pore water sampling procedure. Pore water samples were collected with a $70 \mathrm{~cm}$ long, custom-made, Teflon sampler (13/ $6 \mathrm{~mm}$, outer/inner diameter) equipped with 4 holes $(3 \mathrm{~mm}$ diameter) for every $1 \mathrm{~cm}$ of the lower $10 \mathrm{~cm}$ i.e. a total of 40 holes. At the end of the sampler there was a removable conical tip to facilitate penetration of the peat surface. The sampler was connected to a $500 \mathrm{~mL}$ transfer bottle $\left(\right.$ Pyrex $\left.^{\odot}\right)$ by Teflon tubing $(8 / 6 \mathrm{~mm}$, outer/inner diameter), and the transfer bottle was connected to a custom-made, portable vacuum pump. Even though the air flows in the direction from the transfer bottle to the vacuum pump, diffusion of $\mathrm{Hg}$ originating from the pump constitute a mass transfer in the opposite direction that potentially might contaminate the pore water samples. To avoid potential contamination from the vacuum pump, gold traps were installed between the vacuum pump and the transfer bottle or the filter holder.

Samples were collected by inserting the sampler $10 \mathrm{~cm}$ below the actual GWL and then pumping the pore water into the transfer bottle. Approximately $100 \mathrm{~mL}$ of water was collected from 
5 evenly distributed spots within each experimental plot to create a pooled sample of $500 \mathrm{ml}$. Approximately $150 \mathrm{~mL}$ of the pooled sample was then filtered through an acid washed membrane filter (45 mm diameter, $0.45 \mu$, cellulose nitrate $100 \%$, sterile, Millipore ${ }^{\circledR}$ ) using a $500 \mathrm{~mL}$ filter holder $\left(\right.$ Nalgene $\left.{ }^{\circledR}\right)$. Filter holders were connected to a manifold which in turn was connected to a portable vacuum pump (Prenart equipment ApS, Frederiksberg, Denmark). This set-up allowed four samples to be filtered simultaneously. Immediately after filtration, each sample was transferred to a Teflon bottle (Nalgene ${ }^{\circledR}$ ), put in a plastic bag, and then kept cool on dry ice in the dark. For stream water, a grab sample was taken directly in a similar Teflon bottle without filtration due to the low content of particulate matter. The samples were stored in the laboratory at $+4^{\circ} \mathrm{C}$ until analysis. The $\mathrm{MeHg}$ and total $\mathrm{Hg}$ in the pore water were always determined within a maximum of five days.

Separate tests before the start of the investigation showed negligible losses of $\mathrm{MeHg}$ during five days of storage in the dark and at $4{ }^{\circ} \mathrm{C}$. In an earlier study [45] the stability of spiked (1.0 ng/ $\mathrm{L}) \mathrm{MeHg}$ in river water was determined and only minor losses of $\mathrm{MeHg}$ during the storage of samples was found. After 15 days storage in Teflon containers without additions of preservation reagents the mean concentration of $\mathrm{MeHg}$ was decreased by $6 \%$. (The concentration of $\mathrm{MeHg}$ originally present was $0.35 \mathrm{ng} \mathrm{\textrm {L } ^ { - 1 }}$ and $4.1 \mathrm{ng} \mathrm{Hg}^{2+} \mathrm{L}^{-1}$; TOC was $13 \mathrm{mg} \mathrm{L}^{-1}$ and $\mathrm{pH}$ was 5). Prior to each sampling occasion, the Teflon bottles, transfer bottles, filtering units, filters, Teflon tubing and the Teflon sampler were acid washed with $\mathrm{HCl}$ (p.a. quality, $\mathrm{pH}=2$ ) over night at $70^{\circ} \mathrm{C}$, rinsed three times with Millipore water and thereafter kept in plastic bags prior to the sampling. Plastic gloves were always used during washing and sampling, or when otherwise handling the equipment.

\section{Determination of $\mathrm{Hg}_{\mathrm{tot}}$ and $\mathrm{MeHg}$ in Peat, Pore Water and Stream Samples}

Chemicals were of analytical-reagent grade unless indicated otherwise. All standards and solutions were prepared using Millipore deionized water (Millipore, Bedford, MD, USA).

\section{Digestion and Determination of $\mathrm{Hg}_{\text {tot }}$}

Peat samples. Some $200 \mathrm{mg}$ of peat (wet weight) were weighed and placed into Teflon tubes. Then $4 \mathrm{ml}$ of $\mathrm{HNO}_{3}$ and 4 drops of $\mathrm{HCl}$ were added to samples that were left overnight on a clean bench. After this 10 drops of $\mathrm{H}_{2} \mathrm{O}_{2}$ were added and samples were subsequently heated to $80^{\circ} \mathrm{C}$ for 8 hours. $4 \mathrm{ml}$ of $\mathrm{H}_{2} \mathrm{O}$ were added and after centrifugation the clear solution was used for quantification of $\mathrm{Hg}$. The $\mathrm{Hg}$ species in the samples were reduced using $\mathrm{SnCl}(30 \%)$ to $\mathrm{Hg}^{0}$ that was purged onto gold traps using argon gas. The $\mathrm{Hg}$ adsorbed to gold traps was thermally desorbed followed by analysis using cold vapour atomic absorption spectrometry (CVAAS) at $254 \mathrm{~nm}$ (FIMS, Bodenseewerk Perkin Elmer, Überlingen, Germany) [46]. All samples were analysed at least two times. Tests with addition of 50 and $100 \mu \mathrm{g} \mathrm{HgCl} \mathrm{L}^{-1}$ to one of the samples before acid treatment gave recoveries of 100.9 and $98.7 \%$. Certified reference material (Light sandy soil, BCR 142 with a certified content of $\mathrm{Hg}$ of $67 \pm 11 \mathrm{ng} \mathrm{g}^{-1}$ ) was analysed in the series and gave a value of $74.0 \pm 11.0 \mathrm{ng} \mathrm{g}^{-1}(\mathrm{n}=3)$. The $\mathrm{SO}_{4}{ }^{2-}$ salt used in the field application treatments was analyzed for $\mathrm{Hg}_{\text {tot }}$ which was found to be below the detection limit of $40 \mathrm{pg}$

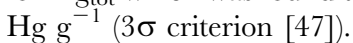

Pore and stream water. Pore water $(30 \mathrm{~mL}), \mathrm{HNO}_{3}(3 \mathrm{~mL}$ ultra pure), and $\mathrm{HCl}(0.5 \mathrm{~mL}$ ultra pure) were added to quartz flasks, which thereafter were subjected to UV radiation for seven hours. After digestion, $5 \mathrm{~mL}$ of a solution containing $30 \% \mathrm{SnCl}$ and $5 \% \mathrm{H}_{2} \mathrm{SO}_{4}$ was added to the sample. The $\mathrm{Hg}^{0}$ formed was thereafter removed during 10 minutes under a constant flow of Argon. $\mathrm{Hg}^{0}$ was amalgamated on a gold trap and thermally desorbed and detected by CVAAS as described above [46].

\section{Extraction and Derivatization Procedure for the Determination of $\mathrm{MeHg}$}

Pore water and streamwater. A modified in situ ethylation method using tetraethylborate [48,49] was employed for analysis of $\mathrm{MeHg}$ concentration in pore water samples [50]. Derivatized $\mathrm{Hg}$ species, trapped to Tenax (Supelco, Bellefonte, PA, USA) columns was thermo-desorbed at $200^{\circ} \mathrm{C}$ and injected into the $\mathrm{GC}$ for determination by Microwave Induced Plasma - Atomic Emission Spectrometer (MIP-AES) [51].

\section{Peat Samples}

A solvent extraction $\left(0.03 \mathrm{M} \mathrm{CuSO}_{4}(3 \mathrm{~mL}), 0.38 \mathrm{M} \mathrm{KBr}\right.$ (3 mL), and $\left.\mathrm{CH}_{2} \mathrm{Cl}_{2}(5 \mathrm{~mL})\right)$ method [52] followed by ethylation using tetraethylborate [49] and GC separation and MIP-AES detection were used for analysis of the total $\mathrm{MeHg}$ content in peat samples [51]. The absolute detection limit for $\mathrm{MeHg}$ determined with the in situ ethylation method was $1.7 \mathrm{pg} \mathrm{L}^{-1}$ as $\mathrm{Hg}$ based on three times the relative standard deviation of repeated blank measurements [47]. For quality assurance of the in situ ethylation procedure standard additions of $\mathrm{MeHg}$ were performed to determine recoveries. These were found to be $0.90-1.05$ for an increase of $\mathrm{MeHg}$ concentrations in the range of $1 \mathrm{ng} \mathrm{L}-1$. The ethylation method provided accurate results (within $2 \%$ of the certified value) for $\mathrm{MeHg}$ when analysing certified reference materials (Tort 2; Dolt 2) and it provided good agreement with results for $\mathrm{MeHg}$ in brackish water $0.12 \pm 0.009 \mathrm{ng} / \mathrm{L}$ compared to $0.1 \pm 0.002 \mathrm{ng} \mathrm{L}^{-1}$ for flow injection-liquid chromatographyCVAAS. For the comparison three determinations were performed with each method. The precision of the in situ ethylation method was typically better than $10 \%$ for the pore water samples. Normally one analysis was performed for each pore water sample.

\section{Statistics}

To compare the pore water $\mathrm{MeHg}$ concentrations between the plots with $20 \mathrm{~kg} \mathrm{~S} \mathrm{ha}^{-1} \mathrm{y}^{-1}$ (HighS) and $3 \mathrm{~kg} \mathrm{~S}^{-1} \mathrm{y}^{-1}$ (LowS) plots, General Linear Model (GLM) statistical analysis (SYSTAT inc.) was run with treatment (HighS, LowS) as the category variable, groundwater level (GWL) as the independent variable and $\mathrm{MeHg}$ concentration as a dependent variable. The GLM was also used to compare the pore water $\mathrm{MeHg}$ concentrations at different depths, with treatment, depth, and date as category variables, while the concentration of $\mathrm{MeHg}$ was the dependent variable.

Statistical comparison of the concentration of $\mathrm{MeHg}, \mathrm{Hg}_{\text {tot }}$, and $\mathrm{S}_{\text {tot }}$ (dependent variables) in the peat organic matter between the HighS and LowS plots was also made using GLM. Here, the category variables used were: treatment (HighS or LowS) or depth $(0-5 \mathrm{~cm}, 5-10 \mathrm{~cm}, 10-20 \mathrm{~cm}, 20-40 \mathrm{~cm})$. GLM was also used for comparing pore water $\mathrm{pH}$ (dependent variable) between the HighS and LowS plots (category variable). All pairwise comparisons within each variable were made using Tukey's test.

\section{Results}

The concentrations of pore water $\mathrm{MeHg}$ were always measured in the top ten centimetres below the water table. The depth of the mire water table relative to the mire surface varied $\sim 15-20 \mathrm{~cm}$ during the measurement period. The variation in pore water $\mathrm{MeHg}$ concentrations may therefore result from both seasonal 
variation in production/consumption of $\mathrm{MeHg}$ at each depth as well as differences in production/consumption between depths. The seasonal mean of the pore water $\mathrm{MeHg}$ concentrations (1.3 $\mathrm{ng} \mathrm{L}^{-1} \pm 0.08, \mathrm{SE} ; \mathrm{n}=42$ ) from the plots receiving additional $\mathrm{SO}_{4}{ }^{2-}(\mathrm{HighS})$ was significantly $(\mathrm{p}<0.0001)$ higher than the $\mathrm{MeHg}$ concentrations $\left(0.6 \mathrm{ng} \mathrm{\textrm {L } ^ { - 1 }} \pm 0.02, \mathrm{SE} ; \mathrm{n}=42\right)$ in the plots receiving ambient levels of $\mathrm{SO}_{4}{ }^{2-}$ (Fig. 1A). A pronounced, systematic seasonal pattern in $\mathrm{MeHg}$ concentrations was found in the Highs plots, but not in the plots receiving ambient $\mathrm{S}$ deposition (3 $\mathrm{kg} \mathrm{ha}^{-1}$, LowS). Generally for both HighS plots the pore water $\mathrm{MeHg}$ level was highest from the beginning of the summer until late July. Thereafter the $\mathrm{MeHg}$ concentrations decreased to the lowest levels from the middle of August to the beginning of September. The pore water concentrations of $\mathrm{MeHg}$ then increased again (Fig. 1A). In the LowS plots, the amplitude of

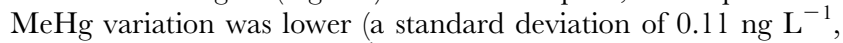
with a range of $0.48 \mathrm{ng} \mathrm{L}^{-1}$ between the highest and the lowest values) than in the High $\mathrm{S}$ plots which had a standard deviation of $0.53 \mathrm{ng} \mathrm{L}^{-1}$ and a range of $2.55 \mathrm{ng} \mathrm{L}^{-1}$ (Fig. 1A).

The concentrations of pore water $\mathrm{MeHg}$ in the HighS plots were positively correlated $\left(r^{2}=0.21 ; p=0.001\right)$ to the $G W L$ at the time of sampling, with the lowest concentrations of $\mathrm{MeHg}$ during the period with lowest GWL (Fig. 1A, B). For the LowS plots there was no correlation between $\mathrm{MeHg}$ concentrations and the local groundwater table $(\mathrm{p}=0.87)$ (Fig. 1A,B).

The mean pore water concentrations of $\mathrm{MeHg}$ decreased with depth from the current GWL down to $40 \mathrm{~cm}$ below, for both the LowS and HighS plots (i.e. samples were taken at a maximum depth of $60 \mathrm{~cm}$ below the vegetation surface; Fig. 2). The decrease in $\mathrm{MeHg}$ concentrations with depth were more pronounced at the plots with enhanced $\mathrm{SO}_{4}{ }^{2-}$ deposition than those with ambient $\mathrm{SO}_{4}{ }^{2-}$ deposition levels (Fig. 2). For the LowS plots the MeHg concentrations at the deepest sampling depth $(30-40 \mathrm{~cm})$ were significantly lower than the three more superficial sampling depths for all three dates of sampling (Fig. 2, upper panel). In the HighS plots the pore water concentrations of $\mathrm{MeHg}$ were significantly $(p<0.0001)$ higher in the two upper sampling depths compared to the two lower sampling depths (Fig. 2, lower panel).

The $\mathrm{MeHg}$ concentrations in the stream runoff (Fig. 1A, mean

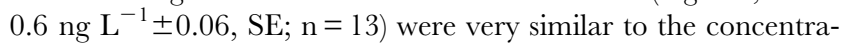
tions measured just below the fluctuating groundwater surface on the ambient deposition plots $\left(0.6 \mathrm{ng} \mathrm{L^{-1 }} \pm 0.02, \mathrm{SE} ; \mathrm{n}=42\right)$ both with regards to absolute concentrations and variability over the course of the year.

The pore water concentrations of $\mathrm{Hg}_{\text {tot }}$ varied between $0.3 \mathrm{ng}$ $\mathrm{L}^{-1}$ (detection limit) and $30 \mathrm{ng} \mathrm{\textrm {L } ^ { - 1 }}$ during the sampling period. No correlations $(\mathrm{p}>0.1)$ between the concentrations of $\mathrm{MeHg}$ and total $\mathrm{Hg}$ were found in any of the four plots, and there were no differences in these concentrations between the HighS plots and the LowS plots $(\mathrm{p}>0.1)$.

The pore water concentrations of $\mathrm{SO}_{4}{ }^{2-}$ were analysed for the period between June $16^{\text {th }}$ and September $22^{\text {nd }}$. Until the beginning of August, during the period with the highest pore water $\mathrm{MeHg}$, the concentrations of $\mathrm{SO}_{4}{ }^{2-}$ in the HighS plots were

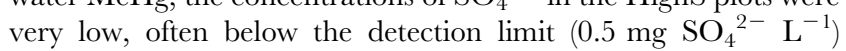
(Fig. 3A). However, during the period when the pore water $\mathrm{MeHg}$ concentrations in the HighS plots were lowest (and thus closest to the more stable $\mathrm{MeHg}$ concentrations in the LowS plots), the highest $\mathrm{SO}_{4}{ }^{2-}$ concentrations in the HighS plots were measured. The $\mathrm{SO}_{4}{ }^{2-}$ concentration in the HighS plots reached their highest levels when the GWL's were deepest, between 15 and $21 \mathrm{~cm}$ below the mire surface (Fig. 3A, B). In the LowS plots the pore water $\mathrm{SO}_{4}{ }^{2-}$ concentrations were always below the detection limit (data not shown).
A seasonal trend in $\mathrm{pH}$ was observed in the HighS plots (Fig. 3B) with a slow decrease in $\mathrm{pH}$ from $4.4( \pm 0.1 \mathrm{SE}, \mathrm{n}=2)$ to 3.8 $( \pm 0.02 \mathrm{SE}, \mathrm{n}=2)$ between June $16^{\text {th }}$ and October $13^{\text {th }}$, (Fig. 3B). The corresponding $\mathrm{pH}$ values in the pore water samples from the LowS plots were $4.0( \pm 0.02 \mathrm{SE}, \mathrm{n}=2)$, and $3.9( \pm 0.02 \mathrm{SE}, \mathrm{n}=2)$, respectively (data not shown). The seasonal mean $\mathrm{pH}$ in the pore water from the HighS plots $(4.0 \pm 0.2 \mathrm{SE}, \mathrm{n}=36)$ was significantly different $(\mathrm{p}=0.002 ; \mathrm{N}=72)$ from the seasonal mean $\mathrm{pH}$ in the LowS plots $(3.9 \pm 0.1 \mathrm{SE}, \mathrm{n}=36)$.

There was a small but steady increase in the concentrations of DOC during the sampling period except in the beginning of June when the DOC concentrations in the LowS plots increased to approximately twice the value of the High S plots (Fig. 4). The highly elevated DOC values on August $25^{\text {th }}$ coincided with the deepest sampling depth for each of the plots (Fig. 1B).

The amount of $\mathrm{S}$ in the peat organic matter ranged between $0.05 \%$ and $0.16 \%$ (Table 1). There was no significant correlation between total $\mathrm{S}$ content in the peat and pore water $\mathrm{MeHg}$. There was no significant difference in the concentration of $\mathrm{MeHg}$ in the peat between the LowS and the HighS plots (Table 1). However, in one of the HighS plots the concentration of $\mathrm{MeHg}$ in the organic matter was substantially larger compared with the LowS plots (Table 1).

The concentrations of total $\mathrm{Hg}$ were several orders of magnitude higher than the concentration of $\mathrm{MeHg}$ in the peat organic matter (Table 1). In the LowS plots there were significantly $(\mathrm{p}<0.001)$ lower concentrations of $\mathrm{Hg}_{\text {tot }}$ in the upper peat $(0-5 \mathrm{~cm})$ compared to the lower depths (Table 1). The concentrations of $\mathrm{Hg}_{\text {tot }}$ in the HighS plots were similar down to $20 \mathrm{~cm}$ peat depth, and thereafter the $\mathrm{Hg}_{\text {tot }}$ concentrations increased significantly $(\mathrm{p}=0.026)$ (Table 1$)$. The peat organic matter $\mathrm{Hg}_{\text {tot }}$ concentrations were significantly $(\mathrm{p}<0.001)$ different between the HighS and the LowS plots. The amount of $\mathrm{Hg}$-tot in the solid phase of the upper $5 \mathrm{~cm}$ was significantly $(\mathrm{p}=0.001)$ higher in the HighS plots compared to the LowS plots. The salt used $\left(\mathrm{Na}_{2} \mathrm{SO}_{4}\right)$ to experimentally increase the load of $\mathrm{S}$ to the plots would cause an increase of $40 \mathrm{pg}$ assuming that all $\mathrm{Hg}$ in the salt added over five years is retained. This amount is three orders of magnitude less than the difference between the $\mathrm{Hg}$ in the upper $5 \mathrm{~cm}$ of the HighS plots relative to the LowS plots. So the content of $\mathrm{Hg}_{\text {tot }}$ in the HighS plots do not emanate from the $\mathrm{Na}_{2} \mathrm{SO}_{4}$ additions.

\section{Discussion}

Boreal mires have earlier been identified as an important source of $\mathrm{MeHg}$ loading to surface waters [20,21,27,53]. There is increasing awareness that $\mathrm{SO}_{4}{ }^{2-}$ is an important control on the strength of mires as a $\mathrm{MeHg}$ source. A number of short term studies have seen this after one to half a dozen $\mathrm{SO}_{4}{ }^{2-}$ amendments, during the course of up to one year $[9,30,35]$. The potential for chronic (multiple years) of $\mathrm{SO}_{4}{ }^{2-}$ addition to increase the mire pore water $\mathrm{MeHg}$ concentration was demonstrated by Branfireun et al. [36] based on data from one point in time during 1997 from the same experimental site used in this study. Our results from the entire snow-free period of 1999 after five years of $\mathrm{SO}_{4}{ }^{2-}$ treatment provide evidence that the elevation of superficial peat pore water $\mathrm{MeHg}$ by long-term $\mathrm{SO}_{4}{ }^{2-}$ deposition can be persistent and endure throughout the snow-free period. The plausibility of peat pore water just below the water table being the source of the $\mathrm{MeHg}$ in runoff from the study wetland was confirmed by the close correspondence between the $\mathrm{MeHg}$ concentrations in the superficial pore water of the LowS plots receiving ambient atmospheric deposition and the stream draining 


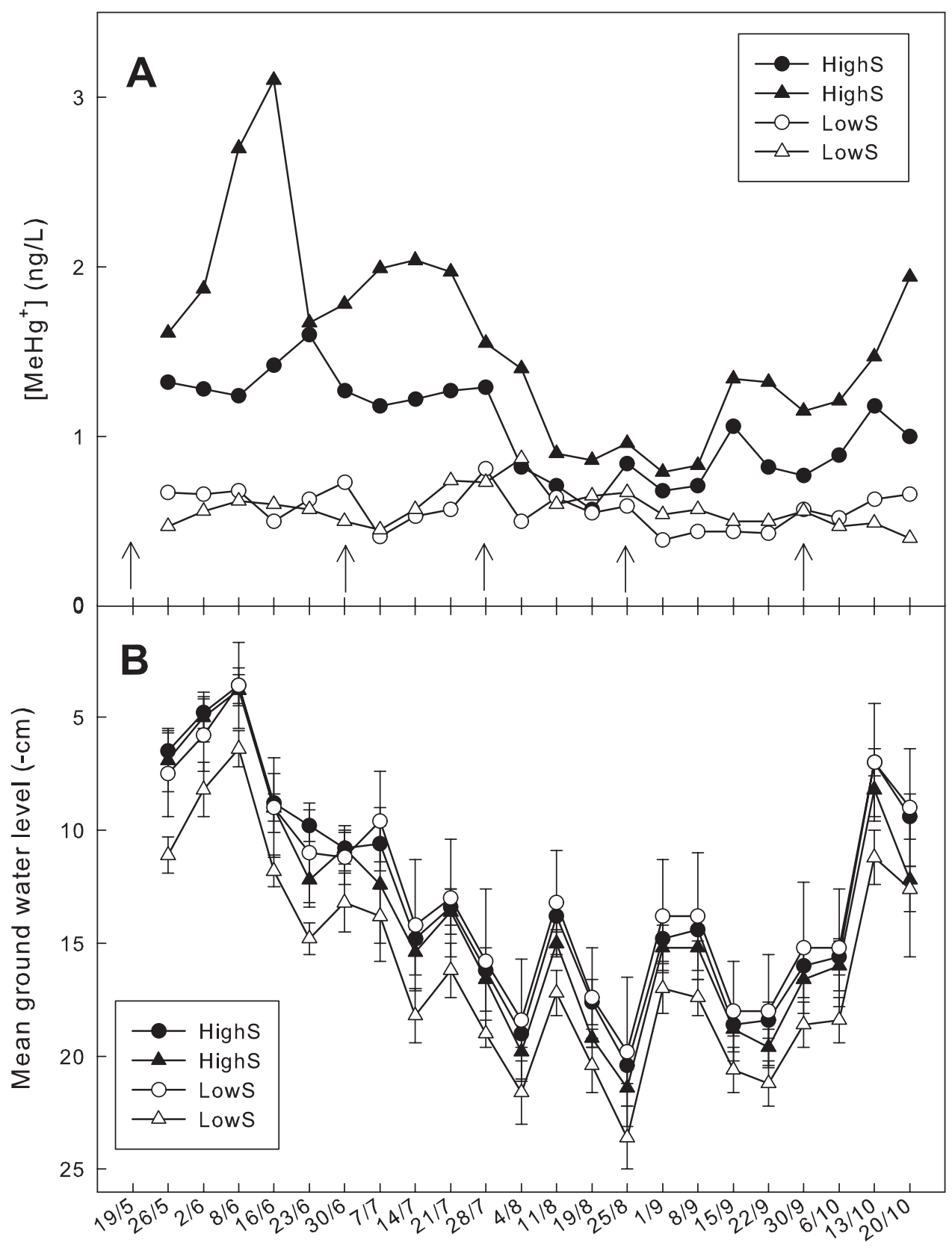

Date of sample collection

Figure 1. Weakly variations in A: concentrations of $\mathrm{MeHg}$ in pore water collected $10 \mathrm{~cm}$ below the groundwater surface at the time of sampling from HighS plots (filled symbols) or LowS plots (open symbols), as well as in the main stream draining the mire where the study was conducted (shaded squares). B: mean groundwater level from the HighS plots (filled symbols) or LowS plots (open symbols). The bars indicate SE. The arrows in A refer to the date on which the plots were fertilised with $\mathrm{SO}_{4}{ }^{2-}$. doi:10.1371/journal.pone.0045547.g001

the study mire (Fig. 1A). Furthermore, the water table level is shown to be a major factor controlling the magnitude of the $\mathrm{MeHg}$ concentration enhancement in peat pore water on the sites with increased $\mathrm{S}$ deposition.

We believe that the persistent elevation of pore water $\mathrm{MeHg}$ concentrations and the connection to water table fluctuation can be explained according to the following conceptual model. Pore water $\mathrm{MeHg}$ is produced by SRB's through the reduction of $\mathrm{SO}_{4}{ }^{2-}[12,31,54]$. Sulphur deposited from the atmosphere to the mire surface is cycled between $\mathrm{SO}_{4}{ }^{2-}$ and hydrogensulphide $\left(\mathrm{H}_{2} \mathrm{~S}\right)$, resulting from the changing redox conditions caused by the vertical movement of the GWL and the presence of SRB microbial communities. The GWL fluctuations depend on variations in evapotranspiration, precipitation and surface water runoff. One aspect of this conceptual model is a transient reduction of the recently deposited $\mathrm{SO}_{4}{ }^{2-}$ by the SRB's with a concomitant transient $\mathrm{Hg}$ methylation $[30,35,55]$. The current study indicates that a chronic deposition of anthropogenic $\mathrm{SO}_{4}{ }^{2-}$ also results in 


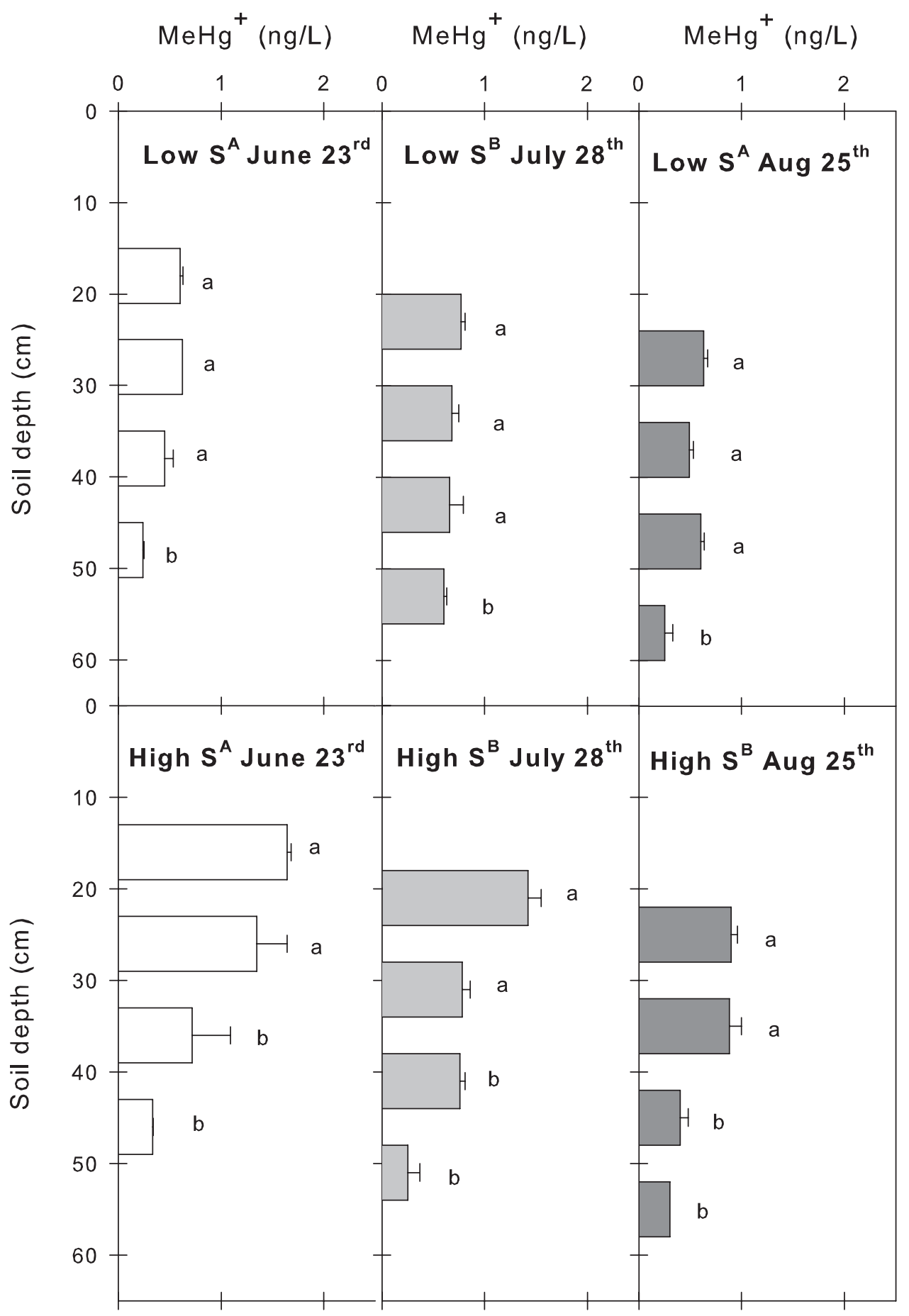

Figure 2. Depth profiles of MeHg pore water concentrations sampled $0-10 \mathrm{~cm}, 10-20 \mathrm{~cm}, 20-30 \mathrm{~cm}$ and $30-40 \mathrm{~cm}$ below the groundwater level at the LowS (upper panel) and HighS (lower panel) plots. The vertical axis refers to the actual peat depths at which the water was sampled. Each bar represents the mean value $( \pm \mathrm{SE})$ of MeHg from two plots for the particular treatment. For each treatment (LowS or HighS), significant differences $(p<0.05)$ in the average pore water MeHg concentration between the sampling dates are designated by different upper case letters. Different lower case letters indicate significant differences $(p<0.05)$ in $\mathrm{MeHg}$ concentrations between depths for each treatment and sampling date.

doi:10.1371/journal.pone.0045547.g002

a more long-term reduction/oxidation cycle of the previously deposited $\mathrm{S}$ which sustains elevated $\mathrm{MeHg}$ levels for weeks after the last precipitation input of $\mathrm{SO}_{4}{ }^{2-}$ to the mire. That long-term redox cycle is driven by the microbial decomposition of organic matter and changing redox-conditions. The possibility of strong internal cycling of $\mathrm{S}$ due to variations in redox conditions has been shown earlier for peatlands $[38,56,57]$.

This conceptual "SRB" model is supported by the temporal variation in pore water $\mathrm{MeHg}$ found in the HighS plots that correlates significantly with the GWL over the season (Fig. 1). 


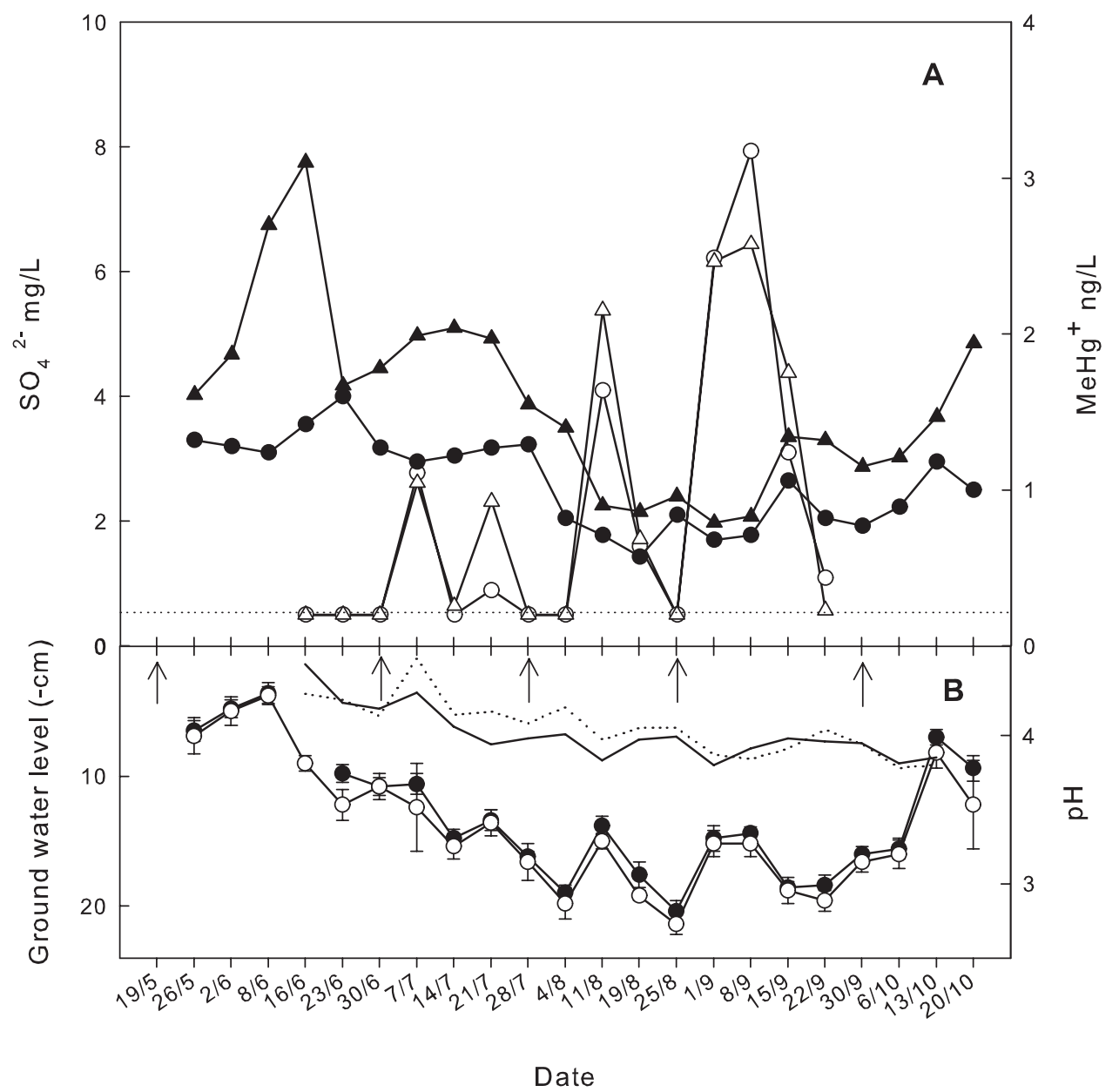

Figure 3. Weakly fluctuations of $\mathrm{A} \mathrm{SO}_{4}{ }^{2-}$ (filled symbols) and pore water $\mathrm{MeHg}$ (open symbols) concentrations, and $\mathrm{B}$ : the groundwater level between June $16^{\text {th }}$ and September $\mathbf{2 2}^{\text {nd }}$ for both HighS plots. The concentration of $\mathrm{SO}_{4}{ }^{2-}$ in the LowS plots was below the detection limit during the sampling period. The dotted line in A indicates the detection limit for $\mathrm{SO}_{4}{ }^{2-}\left(0.5 \mathrm{mg} \mathrm{L}^{-1}\right)$. The $\mathrm{pH}$ in the pore water for the two HighS plots are shown in panel B by the two lines without labels. The arrows in B refer to the date on which the plots were fertilised with $\mathrm{SO}_{4}{ }^{2-}$.

doi:10.1371/journal.pone.0045547.g003

During one distinct period the pore water concentrations of $\mathrm{MeHg}$ in the HighS plots were close to the concentrations found in the plots receiving ambient levels of $\mathrm{SO}_{4}{ }^{2-}$. This period coincided with the lowest GWL and the highest pore water concentrations of $\mathrm{SO}_{4}{ }^{2-}$ measured at the HighS plots (Fig. 3). We interpret this temporal variation in $\mathrm{MeHg}$ as a response to the vertical distribution of the anaerobic heterotrophic bacteria delivering the carbon precursors used by sulphate reducing bacteria. The vertical distribution for other heterotrophic microorganisms in mires, e.g. methanogenic archaea and methanotrophic bacteria is related to the average growing season mire water table level and does not change directly in response to the actual GWL [58-61]. The methanogenic archaea, utilizing the same carbon and energy source as the SRB, has its maxima just below the average depth for the growing season water table level [59-61] indicating competitive exclusion or reduction of methanogens by dissimilatory SRB $[61,62]$. Therefore, when the water table had declined to low levels as a result of the unusually long period of dry summer weather, $\mathrm{SO}_{4}{ }^{2-}$ reduction and concomitant $\mathrm{Hg}$ methylation did not occur fast enough to make use of all the $\mathrm{SO}_{4}{ }^{2-}$ that was available due to a smaller population of SRB. This is in contrast to the situation with higher more normal GWL when our sampling takes place at a level where the SRB community is apparently larger because it can completely exploit the available $\mathrm{SO}_{4}{ }^{2-}$ rapidly enough to keep $\mathrm{SO}_{4}{ }^{2-}$ concentrations below detectable levels, c.f. Eriksson et al. [61].

A decrease in $\mathrm{MeHg}$ concentrations with depth (Fig. 2) also suggests that the methylation activity of the SRB's decreases with depth, and that the effect of enhanced $\mathrm{SO}_{4}{ }^{2-}$ deposition on $\mathrm{Hg}$ methylation is highest within the area of regular groundwater fluctuations. This zone of regularly fluctuating water tables is also the zone that is likely to contribute most to runoff from this type of wetland [63,64]. Altogether this indicates that $\mathrm{SO}_{4}{ }^{2-}$ reduction is restricted at depth. This would be expected and results mainly from the vertical distribution of high quality carbon substrate, acting as an electron donor to the SRBs, which is highest close to the mire surface. Thus, the abundance of SRB's would be relatively lower at these greater depths. (Note that the absolute depth of pore water sampling relative to the mire surface varies with the water table).

While most of the data were consistent with the "SRB" hypothesis, there was one piece of evidence in this study that does not fit with this theory. That is the lack of correlation between solid phase $\mathrm{S}$ in the peat, and pore water $\mathrm{MeHg}$ (Table 1). The 


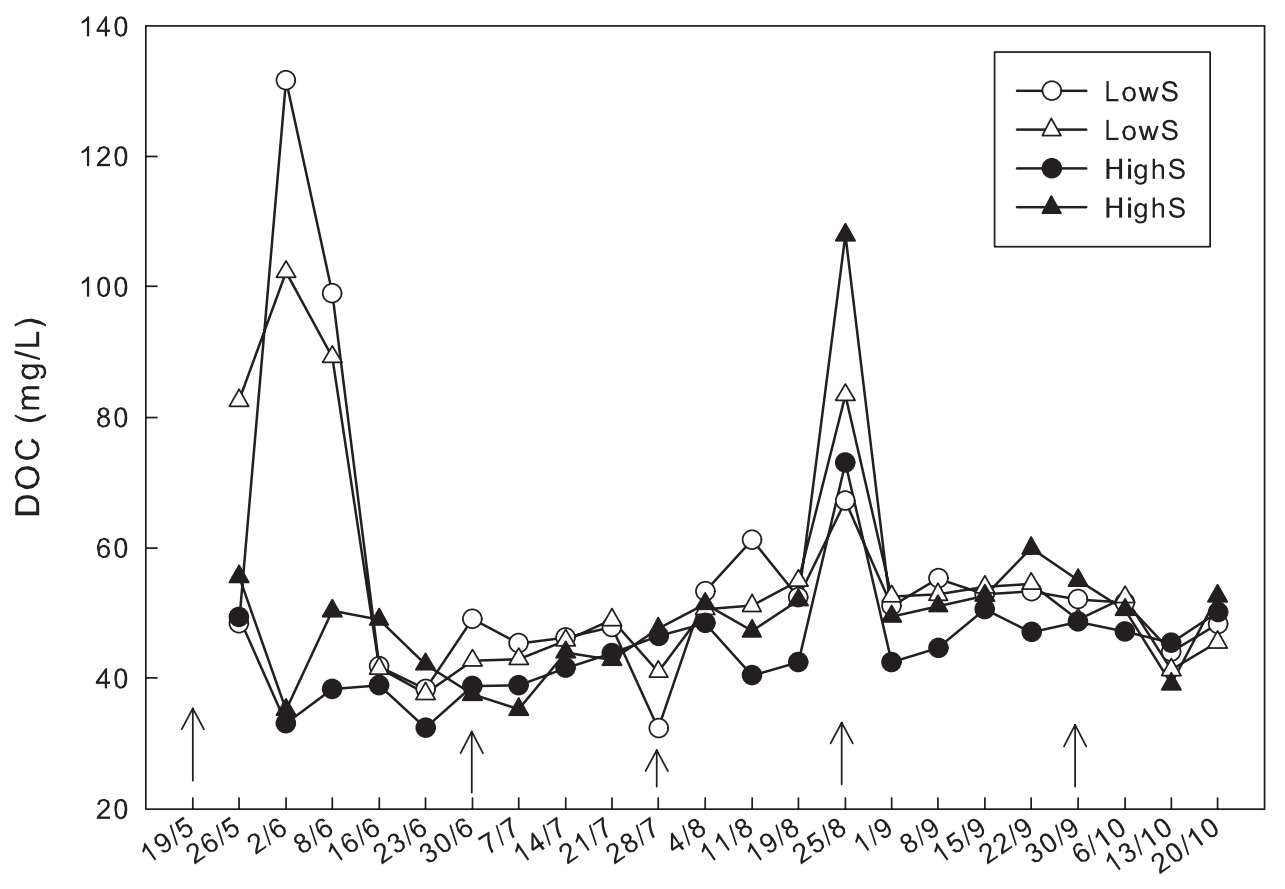

\section{Date of sample collection}

Figure 4. Weakly variation of dissolved organic matter (DOC) for HighS plots (filled symbols) and for LowS plots (open symbols). The arrows refer to the date on which the plots were fertilised with $\mathrm{SO}_{4}{ }^{2-}$. doi:10.1371/journal.pone.0045547.g004

experimental additions of $\mathrm{SO}_{4}{ }^{2-}$ every 4 or 5 weeks during the snow-free period are expected to be reduced within hours or days after addition [30], and indeed $\mathrm{SO}_{4}{ }^{2-}$ was below detection limit for most of the study period, with the one exception during the

Table 1. Content of total $\mathrm{S}\left(\mathrm{S}_{\text {tot }} \%\right), \mathrm{Hg}_{\text {tot }}\left(\mathrm{ng} \mathrm{g}^{-1}\right)$, and $\mathrm{MeHg}$ $\left(\mathrm{ng} \mathrm{g}^{-1}\right)$ in the organic matter at different depths from the two plots receiving $3 \mathrm{~kg} \mathrm{~S} \mathrm{ha}^{-1} \mathrm{yr}^{-1}$ (LowS) or $20 \mathrm{~kg} \mathrm{~S}$ $\mathrm{ha}^{-1} \mathrm{yr}^{-1}$ (HighS).

\begin{tabular}{|c|c|c|c|c|}
\hline Analysis & LowS & LowS & Highs & Highs \\
\hline \multicolumn{5}{|l|}{$\mathrm{S}_{\text {tot }}(\%)$} \\
\hline $0-5 \mathrm{~cm}$ & 0.05 & 0.06 & 0.06 & 0.07 \\
\hline $5-10 \mathrm{~cm}$ & 0.05 & 0.06 & 0.05 & 0.07 \\
\hline $10-20 \mathrm{~cm}$ & 0.07 & 0.09 & 0.10 & 0.12 \\
\hline $20-40 \mathrm{~cm}$ & 0.10 & 0.16 & 0.10 & 0.12 \\
\hline \multicolumn{5}{|c|}{$\mathrm{Hg}_{\text {tot }}\left(\mathrm{ng} \mathrm{g}^{-1}\right.$, S.E., $\mathrm{n}=2$ or 3 ) } \\
\hline $0-5 \mathrm{~cm}$ & $22(6.5)$ & $27(14)$ & $50(8.7)$ & $64(4.0)$ \\
\hline $5-10 \mathrm{~cm}$ & $68(15)$ & $45(1.3)$ & $59(3.2)$ & $63(2.3)$ \\
\hline $10-20 \mathrm{~cm}$ & $65(17)$ & $68(2.2)$ & $66(3.2)$ & $57(0.9)$ \\
\hline $20-40 \mathrm{~cm}$ & $79(5.0)$ & $67(0.6)$ & $89(8.6)$ & $80(0.7)$ \\
\hline \multicolumn{5}{|c|}{$\mathrm{MeHg}\left(\mathrm{ng} \mathrm{g}^{-1}\right)$} \\
\hline $0-5 \mathrm{~cm}$ & 0.17 & 0.30 & 0.20 & 0.76 \\
\hline $5-10 \mathrm{~cm}$ & 0.21 & 0.22 & 0.18 & 3.70 \\
\hline $10-20 \mathrm{~cm}$ & 0.26 & 0.34 & 0.42 & 1.90 \\
\hline $20-40 \mathrm{~cm}$ & 0.20 & 0.93 & 0.18 & 0.26 \\
\hline
\end{tabular}

The solid samples were collected on June $24^{\text {th }} 1999$.

doi:10.1371/journal.pone.0045547.t001 period of low GWL from mid-August to mid-September. Therefore, according to the hypothesis, it is increased concentrations of $\mathrm{S}$ in the organic matter that should feed the persistent effect from the $\mathrm{SO}_{4}{ }^{2-}$ addition found in the HighS plots. Such a correlation between total $\mathrm{S}$ in the peat and elevated pore water $\mathrm{MeHg}$ levels (or even $\mathrm{S}$ additions) was not found in our study. However, in the study from 1997 [36] done on the same site, a positive correlation between pore water $\mathrm{MeHg}$ and $\mathrm{S}$ in the solid phase was found, supporting the hypothesis described above. We believe that more needs to be known about the cycling of $\mathrm{S}$ in the mire to devise measurements better suited to testing this aspect of the SRB hypothesis.

The factors which pore water $\mathrm{MeHg}$ was not related to are also important arguments for the SRB hypothesis. To begin with, there was no correlation between $\mathrm{Hg}_{\text {tot }}$ and $\mathrm{MeHg}$. Such a lack of correlation between pore water $\mathrm{MeHg}$ and $\mathrm{Hg}_{\text {tot }}$ was also found in a variety of aqueous samples $[65,66]$.

High DOC and low pH [67-70] have been shown to correlate to increased $\mathrm{MeHg}$ concentrations in lake water and fish. Neither of these correlations are a direct outcome of the SRB hypothesis, and no such correlations between DOC and $\mathrm{MeHg}$ concentrations were found in this study of peat pore water that is a precursor to runoff. In late August, water was sampled from the lowest peat depth during the season, yielding DOC concentrations twice as high as on the other summer and autumn sampling occasions. This increase in DOC concentration was accompanied by only a very limited increase in $\mathrm{MeHg}$ in the HighS plots. The $\mathrm{pH}$ in the HighS plots was approximately $0.2-0.4 \mathrm{pH}$ units higher than in the LowS plots at the beginning of the snow free season when the HighS plots had the greatest elevation of pore water $\mathrm{MeHg}$ relative to the LowS plots. The microbial reduction of $\mathrm{SO}_{4}{ }^{2-}$ consumes $\mathrm{H}^{+}[71]$ and theoretically, the complete reduction of the added $\mathrm{SO}_{4}{ }^{2-}$ would be sufficient to generate the higher $\mathrm{pH}$ in the 
HighS plots. Thus, neither acidification, DOC nor $\mathrm{Hg}_{\text {tot }}$ could account for the enhanced concentrations and temporal variation of $\mathrm{MeHg}$ after $\mathrm{SO}_{4}{ }^{2-}$ additions.

Another alternative explanation for the enhanced levels of pore water $\mathrm{MeHg}$ found in the HighS plots might be that the microbially produced $\mathrm{MeHg}$ sulphides which increase the partitioning of $\mathrm{MeHg}$ to the water phase [72,73]. However, calculations based on the amount of added $\mathrm{SO}_{4}{ }^{2-}$ revealed that a negligible concentration of $\mathrm{MeHg}$ bound to peat organic matter would be exchanged due to the low $\mathrm{pH}$ in the peat.

\section{Conclusion}

This study demonstrates that chronic deposition of $\mathrm{SO}_{4}{ }^{2-}$ to a boreal mire can result in large and persistent increases in the $\mathrm{MeHg}$ of peat pore water located near the surface of the water table. The increase in pore water $\mathrm{MeHg}$ caused by the addition of $17 \mathrm{~kg} \mathrm{~S}$ ha $\mathrm{yr}^{-1}$ beyond the ambient deposition of $3 \mathrm{~kg} \mathrm{ha}^{-1} \mathrm{yr}^{-1}$ varied strongly over the snow free season in conjunction with seasonal fluctuations of the water table. The conceptual model we present to explain the HighS effect on $\mathrm{MeHg}$ postulates that enhanced pore water $\mathrm{MeHg}$ concentrations are maintained by the cycling of $\mathrm{S}$ as a result of fluctuating redox conditions that stimulate, and presumably increase the SRB community in the immediate vicinity of the redox fluctuation associated with the fluctuating water table.

Since the peat pore water just below the water table can be an important source of $\mathrm{MeHg}$ in runoff from a wetland, we believe these results support the hypothesis that $\mathrm{SO}_{4}{ }^{2-}$ deposition has increased the contribution of peatlands to $\mathrm{MeHg}$ in downstream aquatic systems. This would mean that the increased deposition of $\mathrm{SO}_{4}{ }^{2-}$ in acid rain has contributed to the modern increase in the

\section{References}

1. Travnikov O, Ilyin I (2009) The EMEP/MSC-E mercury modeling system. In: Pirrone N, Mason R, editors. Mercury Fate and Transport in the Global Atmosphere: Springer. 571-587.

2. Steinnes E, Berg T, Sjøbakk TE (2003) Temporal and spatial trends in $\mathrm{Hg}$ deposition monitored by moss analysis. Sci Total Environ 304: 215-219. DOI: 10.1016/S0048-9697(02)00570-3.

3. Johansson K, Bergbäck B, Tyler G (2001) Impact of atmospheric long-range transport of lead, mercury and cadmium on the Swedish forest environment. Water Air Soil Pollut: Focus 1: 279-297. DOI: 10.1023/A:1017528826641.

4. Mason RP, Reinfelder JR, Morel FMM (1996) Uptake, toxicity, and trophic transfer of mercury in a coastal diatom. Environ Sci Technol 30: 1835-1845. DOI: $10.1021 /$ es950373d.

5. Meili M (1997) Mercury in lakes and rivers. Metal ions in biol systems 34: 21-51.

6. Chasar LC, Scudder BC, Stewart RA, Bell AH, Aiken GR (2009) Mercury cycling in stream ecosystems. 3. Trophic dynamics and methylmercury bioaccumulation. Environ Sci Technol 43: 2733-2739. DOI: 10.1021/ es8027567.

7. Downs SG, MacLeod CL, Lester JN (1998) Mercury in precipitation and its relation to bioaccumulation in fish: A literature review. Water Air Soil Pollut 108: 149-187. DOI: 10.1023/A:1005023916816.

8. Conaway CH, Black FJ, Weiss-Penzias P, Gault-Ringold M, Flegal AR (2010) Mercury speciation in Pacific coastal rainwater, Monterey Bay, California. Atmos Environ 44: 1788-1797. DOI: 10.1016/j.atmosenv.2010.01.021.

9. Jeremiason JD, Engstrom DR, Swain EB, Nater EA, Johnson BM, et al. (2006) Sulfate addition increases methylmercury production in an experimental wetland. Environ Sci Technol 40: 3800-3806. DOI: 10.1021/es0524144.

10. Schuster PF, Shanley JB, Marvin-Dipasquale M, Reddy MM, Aiken GR, et al. (2008) Mercury and organic carbon dynamics during runoff episodes from a northeastern USA watershed. Water Air Soil Pollut 187: 89-108.

11. Mitchell CPJ, Branfireun BA, Kolka RK (2009) Methylmercury dynamics at the upland-peatland interface: Topographic and hydrogeochemical controls. Water Resour Res 45: W02406. DOI: 10.1029/2008WR006832.

12. Gilmour CG, Henry EA, Mitchell R (1992) Sulfate stimulation of mercury methylation in freshwater sediments. Environ Sci Technol 26: 2281-2287. DOI: $10.1021 / \mathrm{es} 00035 \mathrm{a} 029$.

13. Watras CJ, Bloom NS, Hudson RJM, Gherini S, Munson R, et al. (1994) Sources and fates of mercury and methylmercury in Wisconsin lakes. In: Watras CJ, Huckabee JW, editors. Mercury pollution integration and synthesis. London: Lewis Publishers. 153-185.
$\mathrm{MeHg}$ burdens of remote lakes hydrologically connected to peatlands, as has also been suggested by other studies $[9,36]$. This would help explain why the catchment yields of $\mathrm{MeHg}$ from small boreal catchments are not well correlated to the atmospheric input of $\mathrm{Hg}[19,74]$. According to this "sulphur rain" hypothesis, the large catchment $\mathrm{MeHg}$ yields are enhanced by the stimulation of $\mathrm{Hg}$ methylation by $\mathrm{SO}_{4}{ }^{2-}$ in acid rain, rather than directly from the $\mathrm{Hg}$ deposition itself or as a consequence of surface water acidification.

The cycling of $\mathrm{MeHg}$ in catchments is complex, and involves numerous biogeochemical and physical controls, many of which remain to be satisfactorily quantified. The findings presented here are not likely to be applicable to all catchments, but if they are applicable to many high-latitude catchments containing peatlands or other areas of anoxic organic sediments, then they represent an important link in our understanding of catchment-scale $\mathrm{Hg}$ cycling with implications for $\mathrm{Hg}$ uptake by fish that extend across the boreal and sub-boreal zones of North America, Europe and Asia.

\section{Acknowledgments}

The authors want to thank Ulf Juto, Susanne Rostmark, and Elinor Lindberg for excellent assistance with the field sampling and laboratory work. We also thank Prof. Ulf Skyllberg for valuable discussions regarding $\mathrm{Hg}$ equilibrium in soil.

\section{Author Contributions}

Conceived and designed the experiments: IB MN. Performed the experiments: IB MN. Analyzed the data: IB KB WF MN. Contributed reagents/materials/analysis tools: QT WF. Wrote the paper: IB KB SÃ... MN.

14. Watras CJ, Morrison KA (2008) The response of two remote, temperate lakes to changes in atmospheric mercury deposition, sulfate, and the water cycle. Can J Fish Aquat Sci 65: 100-116. 10.1139/f07-159|issn 0706-652x.

15. Schwesig D, Matzner E (2001) Dynamics of mercury and methylmercury in forest floor and runoff of a forested watershed in Central Europe. Biogeochem 53: 181-200. DOI: 10.1023/A:1010600600099.

16. Rudd JWM (1995) Sources of methyl mercury to fresh-water ecosystems - A review. Water Air Soil Pollut 80: 697-713. DOI: 10.1007/BF01189722.

17. Branfireun BA, Hilbert D, Roulet NT (1998) Sinks and sources of methylmercury in a boreal catchment. Biogeochem 41: 277-291. DOI: 10.1023/A:1005964603828.

18. Ward DM, Nislow KH, Folt CL (2010) Bioaccumulation syndrome: identifying factors that make some stream food webs prone to elevated mercury bioaccumulation. Ann N Y Acad Sci 1195: 62-83. DOI: 10.1111/j.17496632.2010.05456.x.

19. Lee YH, Bishop KH, Munthe J, Iverfeldt A, Verta M, et al. (1998) An examination of current $\mathrm{Hg}$ deposition and export in Fenno-Scandian catchments. Biogeochem 40: 125-135. DOI: 10.1023/A:1005926321337.

20. Grigal DF (2002) Inputs and outputs of mercury from terrestrial watersheds: A review. Environ Rev 10: 1-39.

21. St Louis VL, Rudd JWM, Kelly CA, Bodaly RA, Paterson MJ, et al. (2004) The rise and fall of mercury methylation in an experimental reservoir. Environ Sci Tech 38: 1348-1358. DOI: 10.1021/es034424f.

22. Branfireun BA, Krabbenhoft DP, Hintelmann H, Hunt RJ, Hurley JP, et al. (2005) Speciation and transport of newly deposited mercury in a boreal forest wetland: a stable mercury isotope approach. Water Resour Res 41: W06016. DOI: 10.1029/2004WR003219.

23. Mitchell CPJ, Branfireun BA, Kolka RK (2008) Spatial characteristics of met methylmercury production hot spots in peatlands. Environ Sci Tech 42: 10101016. DOI: $10.1021 / \mathrm{es} 0704986$.

24. Richardson MC, Branfireun BA, Robinson VB, Graniero PA (2007) Towards simulating biogeochemical hot spots in the landscape: A geographic object-based approach. J Hydrol 342: 97-109. DOI: 10.1016/j.jhydrol.2007.05.016.

25. Tjerngren I, Karlsson T, Björn E, Skyllberg U (2011) Potential Hg methylation and $\mathrm{MeHg}$ demethylation rates related to the nutrient status of different boreal wetlands. Biogeochem 108: 335-350. DOI: 10.1007/s10533-011-9603-1.

26. Tjerngren I, Meili M, Björn E, Skyllberg U (2012) Eight boreal wetlands as sources and sinks for methyl mercury in relation to soil acidity, $\mathrm{C} / \mathrm{N}$ ratio and small-scale flooding. Environ Sci Technol. DOI: 10.1021/es300845x. 
27. Grigal DF (2003) Mercury sequestration in forests and peatlands: A review. J Environ Qual 32: 393-405.

28. Bishop K, Lee YH, Pettersson C, Allard B (1995) Terrestrial sources of methylmercury in surface waters - the importance of the riparian zone on the Svartberget catchment. Water Air Soil Pollut 80: 435-444. DOI: 10.1007/ BF01189693.

29. Demers JD, Driscoll CT, Shanley JB (2010) Mercury mobilization and episodic stream acidification during snowmelt: Role of hydrologic flow paths, source areas, and supply of dissolved organic carbon. Water Resources Res 46: W01511. DOI: $10.1029 / 2008 W R 007021$.

30. Branfireun BA, Roulet NT, Kelly CA, Rudd JWM (1999) In situ sulphate stimulation of mercury methylation in a boreal peatland: Toward a link between acid rain and methylmercury contamination in remote environments. Global Biogeochem Cy 13: 743-750. DOI: 10.1029/1999GB900033.

31. Compeau GC, Bartha R (1985) Sulfate-reducing bacteria: Principal methylators of mercury in anoxic estuarine sediment. Appl Environ Microb 50: 498-502.

32. Ranchou-Peyruse M, Monperrus M, Bridou R, Duran R, Amouroux D, et al. (2009) Overview of mercury methylation capacities among anaerobic bacteria including representatives of the sulphate-reducers: implications for environmental studies. Geomicrobiol J 26: 1-8. DOI: 10.1080/01490450802599227.

33. Gilmour CC, Henry EA (1991) Mercury methylation in aquatic systems affected by acid deposition. Environ Pollut 71: 131-169. DOI: 10.1016/02697491(91)90031-Q.

34. Harmon SM, King JK, Gladden JB, Newman LA (2007) Using sulfate-amended sediment slurry batch reactors to evaluate mercury methylation. Arch Environ Contam Toxicol 52: 326-331. DOI: 10.1007/s00244-006-0071-x.

35. Mitchell CPJ, Branfireun BA, Kolka RK (2008) Assessing sulfate and carbon controls on net methylmercury production in peatlands: An in situ mesocosm approach. Appl Geochem 23: 503-518.

36. Branfireun BA, Bishop K, Roulet NT, Granberg G, Nilsson M (2001) Mercury cycling in boreal ecosystems: The long-term effect of acid rain constituents on peatland pore water methylmercury concentrations. Geophys Res Lett 28: 1227-1230. DOI: 10.1029/2000GL011867.

37. Alewell G, Paul S, Lischeid G, Storck FR (2008) Co-regulation of redox processes in freshwater wetlands as a function of organic matter availability? Sci Total Environ 404: 335-342. DOI: 10.1016/j.scitotenv.2007.11.001.

38. Deppe M, McKnight DM, Blodau C (2010) Effects of short-term drying and irrigation on electron flow in mesocosms of a northern bog and an alpine fen. Environ Sci Technol 44: 80-86. DOI: 10.1021/es901669z.

39. King JK, Saunders EM, Lee RF, Janhnke RA (1999) Coupling mercury methylation rates to sulfate reduction rates in marine sediments. Environ Toxicol Chem 18: 1362-1369. DOI: 10.1002/etc.5620180704.

40. Lambertsson L, Nilsson M (2006) Organic material: The primary control on mercury methylation and ambient methyl mercury concentrations in estuarine sediments. Environ Sci Technol 40: 1822-1829. DOI: 10.1021/es051785h.

41. Weston NB, Joye SB (2005) Temperature-driven decoupling of key phases of organic matter degradation in marine sediments. Proc Nat Acad Sci USA 102: 17036-17040. DOI: $10.1073 /$ pnas.0508798102.

42. Ivanov KE (1981) Water movement in mirelands.: Academic Press. ISBN: 0123764602 .

43. Granberg G, Sundh I, Svensson BH, Nilsson M (2001) Effects of temperature, and nitrogen and sulphur deposition, on methane emission from a boreal mire. Ecology 82: 1982-1998. DOI: 10.1890/0012-9658(2001)082[1982:EOTA$\mathrm{NA}] 2.0 . \mathrm{CO} ; 2$

44. Wiedermann MM, Nordin A, Gunnarsson U, Nilsson MB, Ericsson L (2007) Global change shifts vegetation and plant-parasite interactions in a boreal mire. Ecology 88: 454-464.

45. Lambertsson L, Björn E (2004) Validation of a simplified field-adapted procedure for routine determinations of methyl mercury at trace levels in natural water samples using species-specific isotope dilution mass spectrometry. Anal Bioanal Chem 380: 871-875. DOI: 10.1007/s00216-004-2863-z.

46. Emteborg H, Sinemus H-W, Radziuk B, Baxter DC, Frech W (1996) Gas chromatography coupled with atomic absorption spectrometry - a sensitive instrumentation for mercury speciation. Spectrochim Acta, part B 51: 829-837. DOI: $10.1016 / 0584-8547(96) 01482-6$.

47. Kaiser H (1965) Zum problem der nachweisgrenze. Fres Z Anal Chem 209: 118.

48. Bloom N (1994) Determination of picogram levels of methylmercury by aqueous phase ethylation, followed by cryogenic gas chromatography with cold vapour atomic fluorescence detection. Can J Fish Aquat Sci 46: 1131-1140.

49. Liang L, Horvat M, Bloom NS (1994) An improved speciation method for mercury by GC/CVAFS after aqueous phase ethylation and room temperature precollection. Talanta 41: 371-379.

50. Qvarnström J, Tu Q Frech W, Lüdke C (2000) Flow injection-liquid chromatography-cold vapour atomic absorption spectrometry for rapid determination of methyl- and inorganic mercury. Analyst 125: 1193-1197. 10.1039/B000933O.
51. Lambertsson L, Lundberg E, Nilsson M, Frech W (2001) Applications of enriched stable isotope tracers in combination with isotope dilution GC-ICP-MS to study mercury species transformation in sea sediments during in situ ethylation and determination. J Anal At Spectrom 16: 1296-1301.

52. Qian J, Skyllberg U, Tu Q Bleam F, Frech W (2000) Efficiency of solvent extraction methods for the determination of methyl mercury in forest soils. Fresenius J Anal Chem 367: 467-473.

53. Selvendrian P, Driscoll CT, Montesdeoca MR, Bushey JT (2008) Inputs, storage, and transport of total and methyl mercury in two temperate forest wetlands. J Geophys Res Biogeosci 113: G00C01.

54. Schaefer JK, Rocks SS, Zheng W, Liang L, Gu B, et al. (2011) Active transport, substrate specificity, and methylation of $\mathrm{Hg}(\mathrm{II})$ in anaerobic bacteria. Proc Nat Acad Sci USA 108: 8714-8719.

55. Chen GW, Herr JW (2010) Simulating the effect of sulfate addition on methylmercury output from a wetland. J Environ Eng 136: 354-362. DOI: 10.1061/(ASCE)EE.1943-7870.0000176.

56. Devito KJ, Hill AR (1997) Sulphate dynamics in relation to groundwater Surface water interactions in headwater wetlands of the southern Canadian Shield. Hydrol Process 11: 485-500.

57. Alewell C, Paul S, Lischeld G, Kusel K, Gehre M (2006) Characterizing the redox status in three different forested wetlands with geochemical data. Environ Sci Technol 40: 7609-7615.

58. Lähde E (1967) Vertical distribution of biological activity in peat of some virgin and drained swamp types. Acta For Fenn 81: 1-15.

59. Sundh I, Nilsson M, Granberg G, Svensson BH (1994) Depth distribution of microbial production and oxidation of methane in northern boreal peatlands. Microb Ecol 27: 253-265. DOI: 10.1007/BF00182409.

60. Nedwell DB, Watson A (1995) CH4 production, oxidation and emission in a U.K. ombrotrophic peat bog: Influence of SO42- from acid rain. Soil Biol Biochem 27: 893-903. DOI: 10.1016/0038-0717(95)00018-A.

61. Eriksson T, Öquist MG, Nilsson MB (2010) Effects of decadal deposition of nitrogen and sulfur, and increased temperature, on methane emissions from a boreal peatland. J Geophys Res 115: G04036.

62. Gauci V, Chapman SJ (2006) Simultaneous inhibition of CH4 efflux and stimulation of sulphate reduction in peat subject to simulated acid rain. Soil Biol Biochem 38: 3506-3510. DOI: 10.1016/j.soilbio.2006.05.011.

63. Granberg G, Grip H, Ottosson Löfvenius M, Sundh I, Svensson BH, et al. (1999) A simple model for simulation of water content, soil frost, and soil temperatures in boreal mixed mires. Water Resour Res 35: 3771-3782. DOI: 10.1029/1999WR900216.

64. Judson H, Krupa SL, Krest JM (2004) Ground water recharge and discharge in the central Everglades. Ground Water 42: 1090-1102. DOI: $10.1111 / \mathrm{j} .1745-$ 6584.2004.tb02646.x.

65. Kelly CA, RuddJWM, Louis VL, Heyes A (1995) Is total mercury concentration a good predictor of methyl mercury concentration in aquatic systems. Water Air Soil Pollut 80: 715-724. DOI: 10.1007/BF01189723.

66. Burns DA, Riva-Murray K, Bradley PM, Aiken GR, Brigham ME (2012) Landscape controls on total and methyl Hg in the upper Hudson River basin, New York, USA. J Geophys Res 117: G01034. DOI: 10.1029/2011JG001812.

67. Meili M, Iverfeldt Å, Håkansson L (1991) Mercury in the surface water of Swedish forest lakes -concentrations, speciation and controlling factors. Water Air Soil Pollut 56: 439-453.

68. Snodgrass JW, Jagoe CH, Bryan AL, Brant HA, Burger J (2000) Effects of trophic status and wetland morphology, hydroperiod, and water chemistry on mercury concentrations in fish. Can J Fish Aq Sci 57: 171-180.

69. Kamman NC, Burgess NM, Driscoll CT, Simonin HA, Goodale W, et al. (2005) Mercury in freshwater fish of northeast North America - A geographic perspective based on fish tissue monitoring databases. Ecotoxicol 14: 163-180. DOI: $10.1007 / \mathrm{s} 10646-004-6267-9$.

70. Åkerblom S, Nilsson MB, Yu J, Ranneby B, Johansson K (2012) Temporal change estimation of mercury concentrations in northern Pike (Esox lucius L) in Swedish lakes. Chemosphere 86: 439-445. DOI: 10.1016/j.chemosphere.2011.09.037.

71. Steinmann P, Shotyk W (1997) Chemical composition, pH, and redox state of sulfur and iron in complete vertical porewater profiles from two Sphagnum peat bogs, Jura Mountains, Switzerland. Geochim Cosmo Acta 61: 1143-1163. DOI: 10.1016/S0016-7037(96)00401-2.

72. Drott A, Lambertsson L, Björn E, Skyllberg U (2007) Importance of dissolved neutral mercury sulfides for methyl mercury production in contaminated sediments. Environ Sci Tech 41: 2270-2276. DOI: 10.1021/es061724z.

73. Skyllberg U, Björkman Westin M, Meili M, Björn E (2009) Elevated concentrations of methyl mercury in streams after forest clear-cut: A consequence of mobilization from soil or new methylation? Environ Sci Technol 43: 8535-8541. DOI: 10.1021/es900996z.

74. Drevnick PE, Canfield DE, Gorski PR, Shinneman ALC, Engstrom DR, et al. (2007) Deposition and cycling of sulfur controls mercury accumulation in Isle royale fish. Environ Sci Technol 41: 7266-7272. DOI: 10.1021/es0712322. 